\title{
The redox-sensitive cation channel TRPM2 modulates phagocyte ROS production and inflammation
}

\author{
Anke $\mathrm{Di}^{1}$, Xiao-Pei Gao ${ }^{1}$, Feng Qian, Takeshi Kawamura, Jin Han, Claudie Hecquet, \\ Richard D. Ye, Stephen M. Vogel, and Asrar B. Malik ${ }^{*}$ \\ Department of Pharmacology and Center for Lung and Vascular Biology, College of Medicine, \\ University of Illinois, Chicago, IL, 60612
}

\begin{abstract}
The NADPH oxidase activity of phagocytes and its generation of reactive oxygen species (ROS) is critical for host-defense, but ROS overproduction can also lead to inflammation and tissue injury. Here we report that TRPM2, a non-selective and redox-sensitive cation channel, inhibits ROS production in phagocytic cells and prevents endotoxin-induced lung inflammation in mice. TRPM2-deficient mice challenged with endotoxin (lipopolysaccharide) showed an increased inflammatory signature and decreased survival compared to controls. TRPM2 functions by dampening NADPH oxidase-mediated ROS production through depolarization of the plasma membrane in phagocytes. Since ROS also activates TRPM2, our findings establish a negative feedback mechanism inactivating ROS production through inhibition of the membrane potentialsensitive NADPH oxidase.
\end{abstract}

NADPH oxidase-dependent reactive oxygen species (ROS) production in phagocytic cells in response to infection plays a key role in the mechanism of inflammation ${ }^{1,2}$. Multiple mechanisms including plasma membrane potential changes ${ }^{3,4}$, calcium $\left(\mathrm{Ca}^{2+}\right)$ influx, and $\mathrm{Ca}^{2+}$-dependent protein kinase $\mathrm{Ca}(\mathrm{PKCa})$ activation 5,6 induce NADPH oxidase activation. PKCa phosphorylates the Nox 2 subunit $\mathrm{p} 47^{\text {phox }}$ resulting in its translocation to the plasma membrane, which is needed for the assembly of the oxidase complex ${ }^{6}$. Transient receptor potential-melastatin 2 (TRPM2, also called LTRPC- 2 or TRPC 7,8 ) is a nonselective cation channel permeable to $\mathrm{Na}^{+}$and $\mathrm{Ca}^{2+}$ (selectivity of TRPM2 for $\mathrm{Ca}^{2+}$ over $\mathrm{Na}^{+}$is $\left.0.5-1.6^{9}\right)$. To date, most studies have addressed the influx of $\mathrm{Ca}^{2+}$ through the redoxsensitive TRPM2 channel ${ }^{8,10,11}$. We surmised that TRPM2-induced $\mathrm{Ca}^{2+}$ influx should enhance NADPH oxidase activation through activation of $\mathrm{Ca}^{2+}$ dependent PKC isoforms 5,6 ; however, our studies reported herein show that TRPM2 activation reduces NADPH oxidase-activated ROS production while at the same time increasing membrane depolarization. We addressed the mechanism of TRPM2 regulation of ROS production in

\footnotetext{
Users may view, print, copy, download and text and data- mine the content in such documents, for the purposes of academic research, subject always to the full Conditions of use: http://www.nature.com/authors/editorial_policies/license.html\#terms

*Corresponding author: Department of Pharmacology, The University of Illinois, College of Medicine 835 South Wolcott Avenue, Chicago, IL, 60612 Phone: (312) 996-7635; Fax: (312) 996-1225; abmalik@uic.edu.

${ }_{1}^{1}$ These authors contributed equally to this work.
}

AUTHOR CONTRIBUTIONS: A.D. and A.B.M. designed the study; A.D., X.G., F.Q., T.K., J.H., C.H., S.M.V. performed experiments and data analysis; A.D., R.D.Y., A.B.M. wrote the paper. 
phagocytes and its relationship to membrane potential changes and the functional significance of TRPM2 in mediating endotoxin (lipopolysaccharides, LPS) - induced lung inflammatory injury. We show using a patch clamping approach combined with biochemistry a strong correlation between reduced ROS production and plasma membrane depolarization caused by TRPM2 activation in phagocytic cells. TRPM2 activation increased survival of endotoxemic mice and decreased lung oxidative damage as well as production of inflammatory cytokines and chemokines. Thus, TRPM2, a non-selective cation channel, protects the lung from inflammatory injury by dampening NADPH oxidase activity in phagocytes and lowering ROS production.

\section{RESULTS}

\section{Protective role of TRPM2 in lung inflammation}

In the dextran sulfate sodium (DSS)-induced model of colitis, chemokine production, polymorphonuclear leukocyte (PMN) infiltration, and ulceration were reduced in TRPM2 knockout mice $\left(\operatorname{Trpm} 2^{-/-}\right)^{12}$. We therefore examined whether $\operatorname{Trpm} 2^{-/-}$mice were similarly protected in an endotoxin-induced lung inflammation model. Contrary to DSS-induced colitis inflammation, we observed augmented release of chemokines and proinflammatory cytokines, tumor necrosis factor (TNF), macrophage inflammatory protein 2 (MIP-2), and interleukin 6 (IL-6) in Trpm $2^{-/-}$mouse lungs compared to Trpm $2^{+/+}$mice (Fig. 1a-c). LPS also induced significantly greater lung tissue myeloperoxidase (MPO) activity in $T r p m 2^{-/}$ than $\operatorname{Trpm}^{+/+}$mice (Fig. 1d) indicating augmented sequestration of inflammatory PMN in knock-out mouse lungs. Inflammation induced by LPS is characterized by rapid PMN sequestration in response to release of chemokines and cytokines after activation of the redox-sensitive pro-inflammatory transcription factor NF- $\kappa \mathrm{B}{ }^{13}$. Increased expression of $\mathrm{NF}-\kappa \mathrm{B}$ was also seen in the lungs of $\operatorname{Trpm} 2^{-/-}$mice during LPS-induced inflammation (Supplementary Fig. 1). Furthermore, augmented lung inflammatory cell infiltration, greater lung edema, and decreased survival were observed in the LPS challenged $\operatorname{Trpm} 2^{-/-}$mice (Figure 1e-g). These results demonstrate a protective role of TRPM2 in LPS-induced lung inflammation.

\section{Oxidative lung injury in TRPM2 deficient mice}

Since ROS is crucial for the mechanism of lung inflammation and injury ${ }^{14}$, we next determined whether TRPM2 participates in regulating ROS production. Given that TRPM2 is a non-selective cation channel permeable to $\mathrm{Na}^{+}$and $\mathrm{Ca}^{2+}$, we initially hypothesized that it mediates ROS production in phagocytes by conducting $\mathrm{Ca}^{2+}$ into cells ${ }^{6}$. However, Trpm $^{-/-}$mice had augmented ROS production from PMN and bone marrow derived macrophages (BMDM) stimulated with LPS or phorbol-12 myristate-13 acetate (PMA) (Figure 2a-d). The increased ROS production required NADPH oxidase since diphenyleneiodonium (DPI, an inhibitor of NADPH oxidase ${ }^{15}$ ) prevented ROS production in both $\mathrm{Trpm}^{+/+}$and $\mathrm{Trpm}^{-/-}$macrophages (Figure 2c). To confirm an inhibitory role of TRPM2 in ROS production, we used DPQ \{ (3,4-dihydro-5-[4-(1piperidinyl)butoxyl]-1(2H)-isoquinolinone $\}$, a cell-permeable poly-ADP-ribose polymerase inhibitor (PARP), which prevents adenosine diphosphoribose (ADPR) generation, to block TRPM2 channel function ${ }^{16,17}$. ROS production from $\operatorname{Trpm} 2^{+/+}$macrophages pretreated 
with DPQ (100 $\mu \mathrm{M}$ for 30 minutes) was increased to the level seen in Trpm $2^{-/-}$ macrophages, whereas DPQ pretreatment did not further increase ROS release from Trpm $2^{-/}$macrophages (Figure 2c,d). To elaborate further on TRPM2's role in blocking ROS production, we determined intracellular ROS levels in Trpm $2^{+/+}$and Trpm $2^{-/-}$ macrophages. ROS production in cells from Trpm $2^{-/-}$mice challenged with PMA or live Escherichia coli was significantly increased compared to $\operatorname{Trpm} 2^{+/+}$mice cells (Supplementary Figure 2a). Trpm $2^{-/}$-mice also showed less bacterial burden compared to wild type (Supplementary Figure 2b), whereas the extent of phagocytosis was unaltered (Supplementary Figure 2c). To evaluate the contribution of oxidative damage in mediating lung inflammatory injury seen in $T r p m 2^{-/-}$mice, we first used immunochemistry to assess 8-hydroxydeoxyguanosine ( $8 \mathrm{OHdG}$ ) levels (a sensitive marker of oxidative damage of DNA ${ }^{18}, 19$ ) in mouse lungs. $8 \mathrm{OHdG}$ expression in $\operatorname{Trpm} 2^{-/-}$lungs was markedly greater than in $\operatorname{Trpm} 2^{+/+}$lungs (Figure 2e, f). The increased TNF production by macrophages from Trpm $2^{-/-}$mice was reduced to the same level seen in macrophages from $\operatorname{Trpm} 2^{+/+}$mice when the former cells were treated with DPI (Figure $2 \mathrm{~g}$ ). We also observed augmented injury of endothelial cells interacting with LPS-stimulated macrophages from Trpm $2^{-/-}$ mice compared to macrophages from $\operatorname{Trpm} 2^{+/+}$mice (Supplementary Figure 3), indicating greater potential of TRPM2 null phagocytes to injure the interacting target cells (in this case endothelial cells) than wild type phagocytes. These results show that inhibition of phagocytic cell ROS production is an important mechanism of TRPM2-mediated protection in LPS-induced inflammation.

\section{TRPM2 modulation of membrane potential regulates ROS}

We next investigated the mechanism of TRPM 2 inhibition of ROS production in phagocytic cells. We initially surmised that TRPM2 as a $\mathrm{Ca}^{2+}$ permeable channel would induce ROS production because of the role of $\mathrm{Ca}^{2+}$ in activating NADPH oxidase through $\mathrm{Ca}^{2+}$ dependent $\mathrm{PKCa}$ in phagocytes ${ }^{6}$; however, the marked ROS production persistent in the absence of TRPM2 activation (Figure 2a-d) pointed to another pathway. Indeed PMAinduced activation of PKCa in BMDM was unchanged regardless of TRPM2 expression (Figure 3a). Moreover, $\mathrm{p} 47^{\text {phox }}$ phosphorylation induced by PMA was similar between $\operatorname{Trpm}^{-/-}$and Trpm $2^{+/+}$macrophages (Figure 3b), suggesting that the mechanism of ROS production in Trpm $2^{-/-}$macrophages lies beyond NADPH oxidase complex assembly. Thus, we tested the hypothesis that TRPM2 controls ROS production through regulating the membrane potential of phagocytes because NADPH oxidase activity and membrane potential are linked ${ }^{3,4,20}$. We measured ROS production at different membrane potentials induced by changing the extracellular potassium $\left(\mathrm{K}^{+}\right)$concentration. A strong correlation was seen between decreased membrane potential (depolarization) and increased extracellular $\mathrm{K}^{+}$in mouse BMDM (Supplementary Figure 4). Likewise increased ROS production in Trpm $2^{-/-}$macrophages was reduced to the level seen in $\operatorname{Trpm} 2^{+/+}$macrophages when membrane potential was controlled at the same level by increasing extracellular $\mathrm{K}^{+}$(to 120 $\mathrm{mM}$ ) in both $\operatorname{Trpm} 2^{-/-}$and $\operatorname{Trpm} 2^{+/+}$macrophages (Figure 3c, d). We next determined using patch clamping whether TRPM2 activation directly altered the membrane potential. ADPR, a potent activator of TRPM $2{ }^{8}$, added through a patching pipette significantly depolarized the plasma membrane (from $-78 \pm 6 \mathrm{mV}$ to $-14 \pm 6 \mathrm{mV}$ ) in Trpm $2^{+/+}$macrophages but not in the $T r p m 2^{-/}$macrophages (from $-82 \pm 5 \mathrm{mV}$ to $-74 \pm 7 \mathrm{mV}$ ) (Figure $4 \mathrm{a}, \mathrm{b}$ ). Although 
PMA depolarized the plasma membrane of both $\operatorname{Trpm} 2^{+/+}$macrophages (from $-81 \pm 2 \mathrm{mV}$ to $-10 \pm 4 \mathrm{mV}$ ) and $\operatorname{Trpm}^{-/-}$macrophages (from $-82 \pm 2 \mathrm{mV}$ to $-50 \pm 8$ ), it caused a significantly lower depolarization in Trpm $2^{-/-}$macrophages (Figure 4c, d). This difference in membrane potential between $\operatorname{Trpm} 2^{+/+}$and $\operatorname{Trpm} 2^{-/-}$cells and its relationship to ROS release is shown in Figure 4e.

To validate the hypothesis that TRPM2 regulates ROS production through altering the membrane potential, we next addressed the role of $\mathrm{Na}^{+}$entry through TRPM2 in mediating inhibition of ROS production. First we determined whether ROS production can be restored to normal levels in $\mathrm{Trpm}^{-/-}$macrophages by providing an artificial cationic conductance with gramicidin, a non-selective $\mathrm{Na}^{+}$-permeable channel that depolarizes the plasma membrane 21, 22. ROS production induced by PMA in both $\operatorname{Trpm} 2^{+/+}$and $\operatorname{Trpm} 2^{-/-}$ macrophages was reduced to the same level in the presence of gramicidin $(40 \mu \mathrm{g} / \mathrm{ml})$ (Figure 4f). We also determined the contribution of $\mathrm{Na}^{+}$entry through TRPM2 in regulating ROS production by measuring changes in ROS production elicited by PMA in solution containing $\mathrm{N}$-methyl-D-glucamine (NMDG) instead of $\mathrm{Na}^{+}$. We surmised that $\mathrm{Na}^{+}$removal should mimic the effects of TRPM2 ablation and $\operatorname{Trpm}^{+/+}$cells should therefore produce more ROS in the presence of NMDG. Substitution of $\mathrm{Na}^{+}$by NMDG augmented ROS production in Trpm $2^{+/+}$cells whereas it had little effect in $\operatorname{Trpm}^{-/-}$cells (Figure 4f). These results together demonstrate that TRPM2 profoundly downregulates NADPH oxidase-mediated ROS production through cation influx-dependent depolarization of plasma membrane potential (see illustration in Supplemental Figure 5) .

\section{LPS activates TRPM2 through ROS generation}

TRPM2 can be activated by binding of ADPR to the nudix-box (NUDT9-H) in its C terminus ${ }^{23-25}$ and through ROS-mediated generation of ADPR ${ }^{26}$. Addition of $200 \mu \mathrm{M}$ ADPR through the patch pipette elicited a linear, non-selective cation current in both PMN and BMDM and isosmotic replacement of external $\mathrm{Na}^{+}$by the impermeant organic cation NMDG abolished the inward current (Supplemental Figure 6a-d). Trpm $2^{-/-}$PMN and Trpm2 ${ }^{-/-}$BMDM failed to respond to ADPR. We also determined TRPM2 activation by $\mathrm{H}_{2} \mathrm{O}_{2}$, a known TRPM2 activating ROS ${ }^{27,28}$. Perfusion of cells with $\mathrm{H}_{2} \mathrm{O}_{2}(300 \mu \mathrm{M})$ elicited a non-selective cation current in $\operatorname{Trpm} 2^{+/+} \mathrm{PMN}$ and isosmotic replacement of external $\mathrm{Na}^{+}$by NMDG abolished the inward current. Although perfusion of cells with $\mathrm{H}_{2} \mathrm{O}_{2}$ also activated a small outward current in $\operatorname{Trpm} 2^{-/-}$cells, $\mathrm{H}_{2} \mathrm{O}_{2}$ failed to induce this current in Trpm2 $2^{-/}$cells (Supplemental Figure 6e). Blocking the inward $\mathrm{Na}^{+}$current with NMDG resulted in left-shift in the reversal potential (membrane potential at zero transmembrane current; inset in Supplemental Figure 6e shows the shift). These findings demonstrate that the cells are hyperpolarized in the absence of $\mathrm{Na}^{+}$, therefore favoring ROS production.

We took advantage of TRPM2 permeability to $\mathrm{Ca}^{2+}$ to study TRPM2 activation by monitoring $\mathrm{Ca}^{2+}$ influx using fura-2. LPS $(1 \mu \mathrm{g} / \mathrm{ml})$ added to extracellular medium induced a transient increase of intracellular $\mathrm{Ca}^{2+}$ in BMDM from $\operatorname{Trpm}^{+/+}$mice (Figure 5a, b). The intracellular $\mathrm{Ca}^{2+}\left(\left[\mathrm{Ca}^{2+}\right]_{\mathrm{i}}\right)$ increase induced by LPS was significantly reduced in cells from Trpm $2^{-/}$mice. The LPS-induced $\left[\mathrm{Ca}^{2+}\right]_{\mathrm{i}}$ increase was also sensitive to NADPH oxidase 
inhibition using DPI (Figure 5a,b). These results show that LPS-induced production of ROS activates TRPM2.

We also used fura- 2 to measure $\left[\mathrm{Ca}^{2+}\right]_{\mathrm{i}}$ increase induced by $\mathrm{H}_{2} \mathrm{O}_{2} \cdot\left[\mathrm{Ca}^{2+}\right]_{\mathrm{i}}$ increase induced by $\mathrm{H}_{2} \mathrm{O}_{2}$ was significantly reduced in the cells from Trpm $2^{-/}$mice (Figure $5 \mathrm{c}$, d). The increase in $\left[\mathrm{Ca}^{2+}\right]_{\mathrm{i}}$ in $\operatorname{Trpm}^{+/+}$macrophages pretreated with DPQ $(100 \mu \mathrm{M})$ was reduced to the level seen in $\operatorname{Trpm}^{-/-}$macrophages, whereas DPQ produced no further decrease $\left[\mathrm{Ca}^{2+}\right]_{\mathrm{i}}$ in $T r p m 2^{-I}$ macrophages (Figure 5c,d). These results show the key role of ADPR in mediating ROS-induced activation of TRPM2.

\section{Compensation for $\mathrm{Ca}^{2+}$ entry secondary to TRPM2 deletion}

We next addressed the possibility that TRPM2 deletion may lead to enhanced $\mathrm{Ca}^{2+}$ signaling induced by stimuli through other redox-sensitive $\mathrm{Ca}^{2+}$ channels. We determined changes in intracellular $\mathrm{Ca}^{2+}$ induced by platelet-activating factor (PAF), a $\mathrm{Ca}^{2+}$-mobilizing agonist ${ }^{29}$ that fails to induce oxidative burst (except at very high concentration $\left.\sim 1 \mu \mathrm{M}\right)^{30}$. We therefore avoided any confounding effect of the ensuing membrane depolarization to reduce the driving force for $\mathrm{Ca}^{2+}$ entry in cells as shown above. Addition of PAF $(0.1 \mu \mathrm{M})$ increased $\left[\mathrm{Ca}^{2+}\right]_{\mathrm{i}}$ with two-peaks, a initial rapid response with high amplitude followed by a slow, lower amplitude response in cells from both $\operatorname{Trpm}^{+/+}$and $\operatorname{Trpm} 2^{-/-}$mice (Figure 5e,f). Importantly, PAF did not induce ROS production in BMDM from both Trpm $2^{+/+}$and Trpm $2^{-/-}$mice (Supplemental Fig. 7). There was also no difference in $\left[\mathrm{Ca}^{2+}\right]_{\mathrm{i}}$ increase induced by PAF between Trpm $2^{+/+}$and Trpm $2^{-/-}$BMDM (Figure 5e,f). Therefore TRPM2 deletion did not increase $\left[\mathrm{Ca}^{2+}\right]_{\mathrm{i}}$ induced by PAF in the absence of ROS production.

Since compensatory ion channel expression and activation may be induced in the knockout mouse model, we next determined whether $\mathrm{Ca}^{2+}$-activation of the non-selective cation (CAN) channels ${ }^{31,32}$ is altered in Trpm $2^{-1-}$ cells. CAN channels were studied since they also regulate membrane potential ${ }^{33}$. TRPM4 and TRPM5 have been identified as two CAN class channels $31,32,34,35$. Addition of $100 \mu \mathrm{M} \mathrm{Ca}^{2+}$ through the patch pipette elicited a highly outward rectified non-selective cation current in both Trpm $2^{+/+}$and Trpm $2^{-/-}$ macrophages (Supplemental Figure 8). The property of this outward rectified current (the amplitude of the current at positive potential is greater than the currents at negative potential) induced by $\mathrm{Ca}^{2+}$ is consistent with reports about TRPM4 and TRPM5 $5^{32,34,35}$. Our results show that CAN (or TRPM4 and TRPM5) activation was not affected by TRPM2 deletion (Supplemental Figure 8). Thus, TRPM2 deletion was not compensated by changes in activation of other related family members, TRPM4 and TRPM5, and compensation of these channels is unlikely to explain the marked differences in lung inflammatory injury between $\operatorname{Trpm}^{+/+}$and $\operatorname{Trpm}^{-/-}$mice shown above.

\section{DISCUSSION}

TRPM2 has been found in many cell types of the immune system, including dendritic cells (DCs), PMN, monocytes, macrophages and lymphocytes ${ }^{36,37}$ however the function of TRPM2 in these cells has remained elusive. The oxidant-dependent mechanism of activation of TRPM2 suggests the involvement of this channel in pathogenic processes such as carcinogenesis, inflammation, ischemia-reperfusion injury, neurodegenerative disorders and 
diabetes (see review ${ }^{37}$ ). In these studies, TRPM2 channel has emerged as an important $\mathrm{Ca}^{2+}$ signaling mechanism contributing to cellular functions such as cytokine production, insulin release, cell motility and cell death ${ }^{37}$. In DCs, TRPM2 regulates intracellular $\mathrm{Ca}^{2+}$ levels and is required for optimal DC maturation and chemotaxis ${ }^{36}$. DCs express TRPM2 preferentially in endolysosomal compartments, which release $\mathrm{Ca}^{2+}$ on exposure to intracellular ADPR or stimulation by chemokines. In monocytes, the impairment of chemokine production in cells lacking TRPM2 was linked to a defect in TRPM2-mediated $\mathrm{Ca}^{2+}$ influx ${ }^{12,37}$. Our study reveals a novel TRPM2 function in which TRPM2 acts as an essential modulator of plasma membrane potential by conducting the influx of cations including both $\mathrm{Ca}^{2+}$ and $\mathrm{Na}^{+}$. Our results in phagocytic cells show that activation of the redox-sensitive TRPM2 inhibits ROS production suggesting that TRPM2 serves as a crucial negative feedback mechanism of ROS production.

The question arises how TRPM2, a member of the TRP family of non-selective cation channels, down-regulates ROS production. Superoxide $\left(\mathrm{O}_{2}^{-}\right)$is generated upon NADPH oxidase assembly and activation through transfer of electrons from cytosolic NADPH to extracellular oxygen ${ }^{38,39}$. Electron flux associated with membrane depolarization ${ }^{40}$ would therefore inhibit any further transfer of electrons across the membrane by NADPH oxidase if a compensating charge is not provided. This could explain the voltage dependence of NADPH oxidase activity ${ }^{4,41}$. To facilitate ROS production, the transferred extracellular electrons must be neutralized by protons $\left(\mathrm{H}^{+}\right)$transported extracellularly through voltagegated proton channels ${ }^{3,42}$. Voltage-gated proton channels are open when the plasma membrane is depolarized during NADPH oxidase activation. By moving positive charge $\left(\mathrm{Ca}^{2+}\right.$ and $\left.\mathrm{Na}^{+}\right)$across the plasma membrane, TRPM2 induces membrane depolarization and thereby inhibits electrogenic activity of NADPH oxidase and blocks $\mathrm{O}_{2}{ }^{-}$production. Although there is no doubt about the voltage-dependent nature of NADPH oxidase activity, the range of voltage-dependence has varied in different studies. It was reported that NADPH oxidase is voltage-independent from $-100 \mathrm{mV}$ to $>0 \mathrm{mV}^{3}$, but it is steeply inhibited by further depolarization, and abolished at about $+190 \mathrm{mV}^{3}$. It was later shown that NADPH oxidase activity is markedly voltage-dependent, which steeply decreases with depolarization within the physiological membrane potential range ( -60 to $60 \mathrm{mV})$. The previously described apparent voltage-independence was attributed to limitation of the substrate, $\mathrm{NADPH}$, and not to any intrinsic property of NADPH oxidase ${ }^{41}$. We show that TRPM2 is a non-selective cation channel which conducts positive charge $\left(\mathrm{Ca}^{2+}\right.$ and $\left.\mathrm{Na}^{+}\right)$into phagocytes and thus suppresses NADPH oxidase activity when the plasma membrane is negative. Under these conditions, TRPM2 activation is expected to reduce electron transfer through NADPH oxidase by carrying cations into cells. These results thus identify the key role of TRPM2-dependent inhibition of NADPH oxidase activity in inactivating ROS production.

Ion channels play a critical role in the array of pathological responses to sepsis ${ }^{43}, 44$. The sepsis mediator LPS can either activate or inhibit ion channels ${ }^{44,45}$. Our study describes a protective anti-inflammatory role for TRPM 2 in LPS-induced lung injury and it demonstrates a previously unknown function of TRPM 2 in dampening phagocytic cell NADPH oxidase-mediated ROS production. TRPM2 mediates transmembrane flux of cations down the electrochemical gradient, raising intracellular cation concentration and 
depolarizing the plasma membrane. The depolarization inhibits ROS production in phagocytes and prevents lung inflammatory injury induced by LPS. These findings uncover an intrinsic negative feedback mechanism that functions at the level of the assembled NADPH oxidase complex. TRPM2 activation in phagocytic cells during sepsis may thus have a unique ability to prevent NADPH oxidase-derived ROS production and thereby protect the host against inflammation and tissue injury.

\section{METHODS}

\section{Mice, cell cultures, and reagents}

C57 black 6 (C57BL6) mice were obtained from Charles River Laboratory. Trpm $2^{-/-}$ C57BL/6 mice were a gift from Dr Barbara A Miller (Penn State, PA). Trpm2 ${ }^{-/}$mice were backcrossed with C57BL6 mice for 5 generations to eliminate any background effects on the observed phenotypes. Trpm $2^{-/-}$and wild-type $\left(\operatorname{Trpm}^{+/+}\right)$littermates were used in the present studies. All mice were housed in the University of Illinois Animal Care Facility in accordance with institutional and NIH guidelines. Veterinary care of these animals and related animal experiments was approved by the University of Illinois Animal Resources Center (Chicago, IL). Mouse bone marrow derived macrophage (BMDM) were isolated and cultured as described ${ }^{46}$. Mouse PMN (polymorphonuclear leukocyte) were isolated from murine bone marrow using Percoll density gradients as described ${ }^{47}$. Mouse lung vascular endothelial cells (MLVECs) were isolated from $\operatorname{Trpm} 2^{+/+}$and $\operatorname{Trpm} 2^{-/-}$mice as described ${ }^{48}$. Phorbol-12-myristate-13-acetate (PMA), lipopolysaccharides (LPS, from Escherichia coli 0111:B4), hydrogen peroxide $\left(\mathrm{H}_{2} \mathrm{O}_{2}\right)$ were purchased from Sigma. $\mathrm{PKCa}$, p47, P-PKCa antibodies and antibody that recognizes p47phox phosphorylation at Ser473 were purchased from Cell Signaling.

\section{Whole cell recordings}

Electrophysiological recordings were obtained using a voltage-clamp technique. All experiments were conducted at room temperature $\left(22-24^{0} \mathrm{C}\right)$ using an EPC-10 patch clamp amplifier (HEKA Electronik GmbH, Lambrecht, Germany) and using the Pulse V 8.8 acquisition program (HEKA Electronik GmbH, Lambrecht, Germany). TRPM2 whole cell current were measured using method similar to those described earlier ${ }^{8}$. Currents were elicited by using a series of test pulses range from -110 to $+110 \mathrm{mV}$ (test pulses were 200 $\mathrm{ms}$ in duration and delivered at $2 \mathrm{~s}$ intervals). The holding potential was $0 \mathrm{mV}$. The pipette solution contained (in mM): $135 \mathrm{CsSO}_{3} \mathrm{CH}_{3}, 8 \mathrm{NaCl}, 2 \mathrm{MgCl}_{2}, 0.5 \mathrm{CaCl}_{2}, 1$ EGTA and 10 Hepes, $\mathrm{pH}$ 7.2. ADPR $(200 \mu \mathrm{M})$ or PMA $(1 \mu \mathrm{M})$ were included in the pipette solution or $\mathrm{H}_{2} \mathrm{O}_{2}(300 \mu \mathrm{M})$ was perfused to the cells in order to induce TRPM2 current. To induce $\mathrm{Ca}^{2+}$-activated cation currents, $100 \mu \mathrm{M}$ free $\left[\mathrm{Ca}^{2+}\right]_{\mathrm{i}}$ was included in the pipette solution. The bath solution contained (in $\mathrm{mM}$ ): $145 \mathrm{NaCl}, 2 \mathrm{CaCl}_{2}, 1 \mathrm{MgC}_{2}, 10$ HEPES, $\mathrm{pH}$ 7.4. In some experiments, $145 \mathrm{NaCl}$ in the bath solution was replaced by $145 \mathrm{~N}$-methyl-D-glucamine (NMDG). In perforated patch clamp, about $500 \mathrm{mg}$ solubilized amphotericin B was added in the pipette solution. Whole cell current was analyzed using IGOR software (WaveMetrics, Lake Oswego, OR). 


\section{Plasma membrane potential recordings}

Plasma membrane potential was recorded by current clamp. The pipette solution contained (in $\mathrm{mM}$ ): $135 \mathrm{KCl}, 8 \mathrm{NaCl}, 2 \mathrm{MgC}_{2}, 0.5 \mathrm{CaC}_{2}$, 1EGTA and 10 Hepes, pH 7.2. The bath solution contained (in mM): $5 \mathrm{KCl}, 140 \mathrm{NaCl}, 2 \mathrm{CaCl}_{2}, 1 \mathrm{MgC}_{2}, 10 \mathrm{HEPES}, \mathrm{pH}$ 7.4. In order to study the effect of different extracellular potassium $\left(\mathrm{K}^{+}\right)$concentration on membrane potential in resting cells, sodium $\left(\mathrm{Na}^{+}\right)$in the bath solution was replace by equal amount of $\mathrm{K}^{+}$respectively. In perforated patch clamp, about $500 \mathrm{mg}$ solubilized amphotericin B was added in the pipette solution. Membrane potential changes were analyzed using IGOR software (WaveMetrics, Lake Oswego, OR).

\section{Measurement of ROS production in phagocytic cells}

BMDM or PMN $\left(5 \times 10^{6}\right)$ from both $\operatorname{Trpm} 2^{+/+}$and $\operatorname{Trpm} 2^{-/-}$mice were treated with PMA or LPS. ROS generation in cultured medium was measured using luminol-enhanced chemiluminescence as described ${ }^{49}$. Chemiluminescence was measured in a Wallac 1420 Multilabel Counter (PerkinElmer Life Sciences). Briefly, luminol was added to the coculture medium to a final concentration of $50 \mu \mathrm{M}$, and horseradish peroxidase was added to a final concentration of 40 units $/ \mathrm{ml}$. ROS release was determined after cells were stimulated with various stimulus for the indicated times. The relative concentration of ROS in the culture medium was expressed as counts per second.

\section{Fluorometric measurements of intracellular $\mathrm{Ca}^{2+}$}

Intracellular $\mathrm{Ca}^{2+}\left(\left[\mathrm{Ca}^{2+}\right]_{\mathrm{i}}\right)$ was recorded in single cells as described ${ }^{50}$. Briefly, a Zeiss Axiovert 200 (Zeiss, Germany) inverted microscope was illuminated using a Photon Technology International DeltaRam (Monmouth Junction, NJ) dual wavelength monochrometer-based illumination system with a xenon lamp and a Hammamatsu R928 photon counting photomultiplier and optical coupling to the microscope. Cells were loaded with a $2 \mu \mathrm{M}$ fura- $2 \mathrm{AM}$ for $30 \mathrm{~min}$ in HBSS at $37^{\circ} \mathrm{C}$. Measurement of fura- 2 fluorescence at 340 and $380 \mathrm{~nm}$ was acquired and offline analyzed using PTI Felix 32 software.

\section{Mortality studies}

$\operatorname{Trpm}^{+/+}$and $\operatorname{Trpm}^{-/-}$mice (40 mice/group) were injected with LPS (30 mg/kg, i.p.).

Percentage of surviving mice was documented every $2 \mathrm{hrs}$.

\section{Immunoprecipitation and immunoblotting}

Activation of PKCa was assessed using antibody that recognizes the phosphorylated forms of PKCa and activation of $\mathrm{p} 47^{\text {phox }}$ was assessed using antibody that recognizes phosphorylated Ser473 after p47 was immunoprecipitated with p47 antibody. Antibodies against non-phosphorylated PKCa and p47 were used to assess protein loading.

\section{Measurement of cytokines and chemokines concentration by enzyme-linked immunosorbent assay (ELISA)}

$\operatorname{Trpm} 2^{+/+}$and $\operatorname{Trpm} 2^{-/-}$mice were sacrificed by i.p. anesthetic at designated time points after LPS injection. Whole lungs were then obtained for measurement of cytokine and chemokine concentration. Lungs were homogenized and centrifuged. Supernatants were 
collected for measurement of chemokine concentrations by ELISA using the Bio-Plex Multiplex Cytokine Assay (Bio-Rad).

\section{Lung tissue myeloperoxidase (MPO) activity}

Lung tissue MPO activity was measured as described ${ }^{48}$. Briefly, lungs were homogenized and centrifuged and the supernatant was then collected and mixed with assay buffer $(0.2$ $\mathrm{mg} / \mathrm{ml} \mathrm{o}$-dianisidine hydrochloride and $0.0005 \% \mathrm{H}_{2} \mathrm{O}_{2}$ ). Absorbance change was measured at $460 \mathrm{~nm}$ for $3 \mathrm{~min}$, and MPO activity was calculated as the change in absorbance over time. PMN sequestration was quantified as MPO activity normalized by the final dry lung weight.

\section{Statistical analysis}

Differences in animal survival rate were assessed by log-rank test. Other statistical comparisons were made using two-tailed Student's t test. Experimental values were reported as the means \pm S.E.M (standard error of the mean). Significance between groups was determined using the t-test (two tails) and asterisks indicate a significance difference with the number of experiments in parentheses.

\section{Supplementary Material}

Refer to Web version on PubMed Central for supplementary material.

\section{ACKNOWLEDGMENTS}

We thank Dr. Thomas E. DeCoursey (Rush University Medical Center), Dr. Nicolas Demaurex (University of Geneva), Dr. J. David Lambeth (Emory University School of Medicine), Dr. Mary C Dinauer (Washington University School of Medicine) for insights into the work. We also thank Dr. Barbara A Miller (Pennsylvania State University School of Medicine, PA) for providing Trpm2 $2^{-1-}$ C57BL/6 mice and Guilan Liu and Gang Wang for technical assistance. This work was supported by Parker B. Francis Fellowship in Pulmonary Research and NIH grant P01 HL77806.

\section{REFERENCES}

1. Iles KE, Forman HJ. Macrophage signaling and respiratory burst. Immunol Res. 2002; 26:95-105. [PubMed: 12403349]

2. Gwinn MR, Vallyathan V. Respiratory burst: role in signal transduction in alveolar macrophages. J Toxicol Environ Health B Crit Rev. 2006; 9:27-39. [PubMed: 16393868]

3. DeCoursey TE. Voltage-gated proton channels find their dream job managing the respiratory burst in phagocytes. Physiology (Bethesda). 25:27-40. [PubMed: 20134026]

4. DeCoursey TE, Morgan D, Cherny VV. The voltage dependence of NADPH oxidase reveals why phagocytes need proton channels. Nature. 2003; 422:531-4. [PubMed: 12673252]

5. Fontayne A, Dang PM, Gougerot-Pocidalo MA, El-Benna J. Phosphorylation of p47phox sites by PKC alpha, beta II, delta, and zeta: effect on binding to p22phox and on NADPH oxidase activation. Biochemistry. 2002; 41:7743-50. [PubMed: 12056906]

6. Cathcart MK. Regulation of superoxide anion production by NADPH oxidase in monocytes/ macrophages: contributions to atherosclerosis. Arterioscler Thromb Vasc Biol. 2004; 24:23-8. [PubMed: 14525794]

7. Nagamine K, Kudoh J, Minoshima S, Kawasaki K, Asakawa S, Ito F, Shimizu N. Molecular cloning of a novel putative $\mathrm{Ca} 2+$ channel protein (TRPC7) highly expressed in brain. Genomics. 1998; 54:124-31. [PubMed: 9806837] 
8. Sano Y, Inamura K, Miyake A, Mochizuki S, Yokoi H, Matsushime H, Furuichi K. Immunocyte Ca2+ influx system mediated by LTRPC2. Science. 2001; 293:1327-30. [PubMed: 11509734]

9. Owsianik G, Talavera K, Voets T, Nilius B. Permeation and selectivity of TRP channels. Annu Rev Physiol. 2006; 68:685-717. [PubMed: 16460288]

10. Hecquet CM, Ahmmed GU, Vogel SM, Malik AB. Role of TRPM2 channel in mediating H2O2induced $\mathrm{Ca} 2+$ entry and endothelial hyperpermeability. Circ Res. 2008; 102:347-55. [PubMed: 18048770]

11. Lange I, Yamamoto S, Partida-Sanchez S, Mori Y, Fleig A, Penner R. TRPM2 functions as a lysosomal Ca2+-release channel in beta cells. Sci Signal. 2009; 2:ra23. [PubMed: 19454650]

12. Yamamoto S, Shimizu S, Kiyonaka S, Takahashi N, Wajima T, Hara Y, Negoro T, Hiroi T, Kiuchi Y, Okada T, Kaneko S, Lange I, Fleig A, Penner R, Nishi M, Takeshima H, Mori Y. TRPM2mediated $\mathrm{Ca} 2+$ influx induces chemokine production in monocytes that aggravates inflammatory neutrophil infiltration. Nat Med. 2008; 14:738-47. [PubMed: 18542050]

13. Guo RF, Ward PA. Role of oxidants in lung injury during sepsis. Antioxid Redox Signal. 2007; 9:1991-2002. [PubMed: 17760509]

14. Chow CW, Abreu M. T. Herrera, Suzuki T, Downey GP. Oxidative stress and acute lung injury. Am J Respir Cell Mol Biol. 2003; 29:427-31. [PubMed: 14500253]

15. Cross AR, Jones OT. The effect of the inhibitor diphenylene iodonium on the superoxidegenerating system of neutrophils. Specific labelling of a component polypeptide of the oxidase. Biochem J. 1986; 237:111-6. [PubMed: 3800872]

16. Fonfria E, Marshall IC, Benham CD, Boyfield I, Brown JD, Hill K, Hughes JP, Skaper SD, McNulty S. TRPM2 channel opening in response to oxidative stress is dependent on activation of poly(ADP-ribose) polymerase. Br J Pharmacol. 2004; 143:186-92. [PubMed: 15302683]

17. Suto MJ, Turner WR, Arundel-Suto CM, Werbel LM, Sebolt-Leopold JS. Dihydroisoquinolinones: the design and synthesis of a new series of potent inhibitors of poly(ADP-ribose) polymerase. Anticancer Drug Des. 1991; 6:107-17. [PubMed: 1903948]

18. Ding Y, Yamada S, Wang KY, Shimajiri S, Guo X, Tanimoto A, Murata Y, Kitajima S, Watanabe T, Izumi H, Kohno K, Sasaguri Y. Overexpression of peroxiredoxin 4 protects against high-dose streptozotocin-induced diabetes by suppressing oxidative stress and cytokines in transgenic mice. Antioxid Redox Signal. 13:1477-90. [PubMed: 20446767]

19. Khan SJ, Pham S, Wei Y, Mateo D, St-Pierre M, Fletcher TM, Vazquez-Padron RI. Stress-induced senescence exaggerates postinjury neointimal formation in the old vasculature. Am J Physiol Heart Circ Physiol. 298:H66-74. [PubMed: 19855064]

20. Murphy R, DeCoursey TE. Charge compensation during the phagocyte respiratory burst. Biochim Biophys Acta. 2006; 1757:996-1011. [PubMed: 16483534]

21. Kelkar DA, Chattopadhyay A. The gramicidin ion channel: a model membrane protein. Biochim Biophys Acta. 2007; 1768:2011-25. [PubMed: 17572379]

22. El Chemaly A, Okochi Y, Sasaki M, Arnaudeau S, Okamura Y, Demaurex N. VSOP/Hv1 proton channels sustain calcium entry, neutrophil migration, and superoxide production by limiting cell depolarization and acidification. J Exp Med. 207:129-39. [PubMed: 20026664]

23. Minke B, Cook B. TRP channel proteins and signal transduction. Physiol Rev. 2002; 82:429-72. [PubMed: 11917094]

24. Venkatachalam K, Montell C. TRP channels. Annu Rev Biochem. 2007; 76:387-417. [PubMed: 17579562]

25. Pedersen SF, Owsianik G, Nilius B. TRP channels: an overview. Cell Calcium. 2005; 38:233-52. [PubMed: 16098585]

26. Miller BA. The role of TRP channels in oxidative stress-induced cell death. J Membr Biol. 2006; 209:31-41. [PubMed: 16685599]

27. Hara Y, Wakamori M, Ishii M, Maeno E, Nishida M, Yoshida T, Yamada H, Shimizu S, Mori E, Kudoh J, Shimizu N, Kurose H, Okada Y, Imoto K, Mori Y. LTRPC2 Ca2+-permeable channel activated by changes in redox status confers susceptibility to cell death. Mol Cell. 2002; 9:163-73. [PubMed: 11804595]

28. Wehage E, Eisfeld J, Heiner I, Jungling E, Zitt C, Luckhoff A. Activation of the cation channel long transient receptor potential channel 2 (LTRPC2) by hydrogen peroxide. A splice variant 
reveals a mode of activation independent of ADP-ribose. J Biol Chem. 2002; 277:23150-6. [PubMed: 11960981]

29. Randriamampita C, Trautmann A. Biphasic increase in intracellular calcium induced by plateletactivating factor in macrophages. FEBS Lett. 1989; 249:199-206. [PubMed: 2544447]

30. Swain SD, Bunger PL, Sipes KM, Nelson LK, Jutila KL, Boylan SM, Quinn MT. Plateletactivating factor induces a concentration-dependent spectrum of functional responses in bovine neutrophils. J Leukoc Biol. 1998; 64:817-27. [PubMed: 9850166]

31. Vennekens R, Olausson J, Meissner M, Bloch W, Mathar I, Philipp SE, Schmitz F, Weissgerber P, Nilius B, Flockerzi V, Freichel M. Increased IgE-dependent mast cell activation and anaphylactic responses in mice lacking the calcium-activated nonselective cation channel TRPM4. Nat Immunol. 2007; 8:312-20. [PubMed: 17293867]

32. Nilius B, Prenen J, Droogmans G, Voets T, Vennekens R, Freichel M, Wissenbach U, Flockerzi V. Voltage dependence of the Ca2+-activated cation channel TRPM4. J Biol Chem. 2003; 278:30813-20. [PubMed: 12799367]

33. Colquhoun D, Neher E, Reuter H, Stevens CF. Inward current channels activated by intracellular $\mathrm{Ca}$ in cultured cardiac cells. Nature. 1981; 294:752-4. [PubMed: 6275271]

34. Prawitt D, Monteilh-Zoller MK, Brixel L, Spangenberg C, Zabel B, Fleig A, Penner R. TRPM5 is a transient $\mathrm{Ca} 2+-$ activated cation channel responding to rapid changes in $[\mathrm{Ca} 2+]$ i. Proc Natl Acad Sci U S A. 2003; 100:15166-71. [PubMed: 14634208]

35. Launay P, Fleig A, Perraud AL, Scharenberg AM, Penner R, Kinet JP. TRPM4 is a Ca2+-activated nonselective cation channel mediating cell membrane depolarization. Cell. 2002; 109:397-407. [PubMed: 12015988]

36. Sumoza-Toledo A, Lange I, Cortado H, Bhagat H, Mori Y, Fleig A, Penner R, Partida-Sanchez S. Dendritic cell maturation and chemotaxis is regulated by TRPM2-mediated lysosomal Ca2+ release. Faseb J. 2011; 25:3529-42. [PubMed: 21753080]

37. Sumoza-Toledo A, Penner R. TRPM2: A Multifunctional Ion Channel for Calcium Signaling. J Physiol. 2011; 589:1515-1525. [PubMed: 21135052]

38. Schrenzel J, Serrander L, Banfi B, Nusse O, Fouyouzi R, Lew DP, Demaurex N, Krause KH. Electron currents generated by the human phagocyte NADPH oxidase. Nature. 1998; 392:734-7. [PubMed: 9565037]

39. Klebanoff SJ. Oxygen metabolism and the toxic properties of phagocytes. Ann Intern Med. 1980; 93:480-9. [PubMed: 6254418]

40. Bankers-Fulbright JL, Gleich GJ, Kephart GM, Kita H, O’Grady SM. Regulation of eosinophil membrane depolarization during NADPH oxidase activation. J Cell Sci. 2003; 116:3221-6. [PubMed: 12829741]

41. Petheo GL, Demaurex N. Voltage- and NADPH-dependence of electron currents generated by the phagocytic NADPH oxidase. Biochem J. 2005; 388:485-91. [PubMed: 15689187]

42. Demaurex N, Elchemaly A. Physiological roles of voltage-gated proton channels in leukocytes. J Physiol.

43. Buckley JF, Singer M, Clapp LH. Role of KATP channels in sepsis. Cardiovasc Res. 2006; 72:220-30. [PubMed: 16963005]

44. Zorn-Pauly K, Pelzmann B, Lang P, Machler H, Schmidt H, Ebelt H, Werdan K, Koidl B, MullerWerdan U. Endotoxin impairs the human pacemaker current If. Shock. 2007; 28:655-661. [PubMed: 18092381]

45. Umans JG, Salvi D, Murray PT, Wylam ME. Selectivity of endotoxin-induced defect in endothelial calcium mobilization. Kidney Int. 1998; 54:1063-9. [PubMed: 9767522]

46. Zhang X, Goncalves R, Mosser DM. The isolation and characterization of murine macrophages. Curr Protoc Immunol. 2008:1. Chapter 14, Unit 14. [PubMed: 19016445]

47. Xu J, Gao XP, Ramchandran R, Zhao YY, Vogel SM, Malik AB. Nonmuscle myosin light-chain kinase mediates neutrophil transmigration in sepsis-induced lung inflammation by activating beta2 integrins. Nat Immunol. 2008; 9:880-6. [PubMed: 18587400]

48. Garrean S, Gao XP, Brovkovych V, Shimizu J, Zhao YY, Vogel SM, Malik AB. Caveolin-1 regulates NF-kappaB activation and lung inflammatory response to sepsis induced by lipopolysaccharide. J Immunol. 2006; 177:4853-60. [PubMed: 16982927] 
49. Gao XP, Zhu X, Fu J, Liu Q, Frey RS, Malik AB. Blockade of class IA phosphoinositide 3-kinase in neutrophils prevents NADPH oxidase activation- and adhesion-dependent inflammation. J Biol Chem. 2007; 282:6116-25. [PubMed: 17197441]

50. Di A, Krupa B, Nelson DJ. Calcium-G protein interactions in the regulation of macrophage secretion. J Biol Chem. 2001; 276:37124-32. [PubMed: 11479305] 

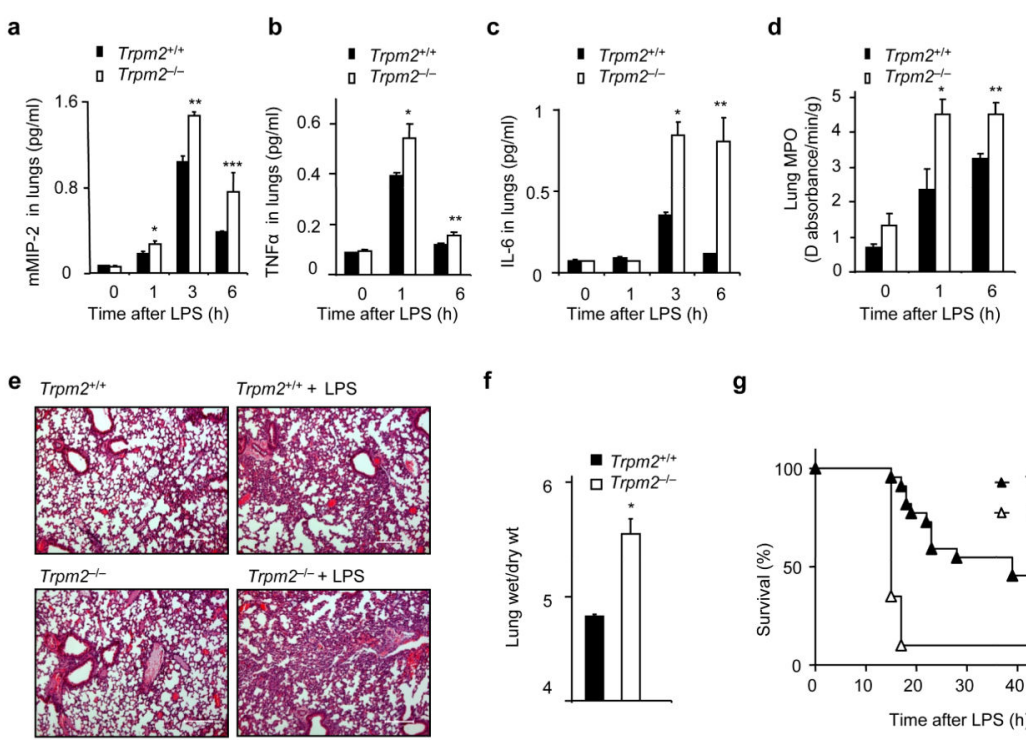

g

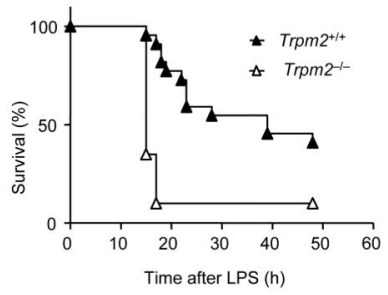

Figure 1. TRPM2 deletion augmented endotoxin-induced lung inflammation and injury (a-c). Augmented LPS-induced production of MIP-2 (a), TNFa (b), and IL-6 (c) in mouse lung after LPS $\left(10 \mathrm{mg} / \mathrm{kg}\right.$, i.p.) challenge in Trpm $2^{-/-}$mice. (a). $* p=0.036(\mathrm{n}=6)$, ** $p=$ $0.0003(\mathrm{n}=6), * * * p=0.0008(\mathrm{n}=6)$, compared to Trpm $2^{+/+}$group; $(\mathbf{b}) . * p=0.036(\mathrm{n}=6)$, ** $p=0.037(\mathrm{n}=6)$, compared to Trpm $2^{+/+}$group; $(\mathbf{c}) . * p=0.018(\mathrm{n}=6), * * p=0.005(\mathrm{n}=$ 6), compared to Trpm $2^{+/+}$group. (d) Lung PMN sequestration as measured by tissue MPO activity. Mice were challenged with LPS $(10 \mathrm{mg} / \mathrm{kg}$, i.p.) for the times indicated. $* p=0.055$ $(\mathrm{n}=3), * * p=0.022(\mathrm{n}=5)$, compared to Trpm $2^{+/+}$group. (e) H\&E (hematoxylin and eosin) staining of lung tissue sections isolated from $\operatorname{Trpm}^{+/+}$and $\operatorname{Trpm}^{{ }^{-/-}}$mice challenged with LPS $\left(20 \mathrm{mg} / \mathrm{kg}\right.$, i.p.) for $20 \mathrm{hr}$. Note the enhanced inflammatory cell infiltration in Trpm $2^{-/-}$ lung after LPS challenge. Scale bar, $200 \mu \mathrm{m}$. (f) Pulmonary edema formation in Trpm $2^{+/+}$ and Trpm $2^{-/-}$lungs after LPS challenge ( $20 \mathrm{mg} / \mathrm{kg}$, i.p.). Edema was measured by increase in wet weight of lungs. $* p=0.006(\mathrm{n}=3)$. $(\mathbf{g})$. TRPM2 expression protects mice from LPSinduced death. Both Trpm $2^{+/+}$and Trpm $2^{-/-}$mouse survival rates were calculated after LPS i.p. injection $(30 \mathrm{mg} / \mathrm{kg})$. Differences in mortality were determined by log-rank test $(p=$ $0.0007, \mathrm{n}=40$ each). 

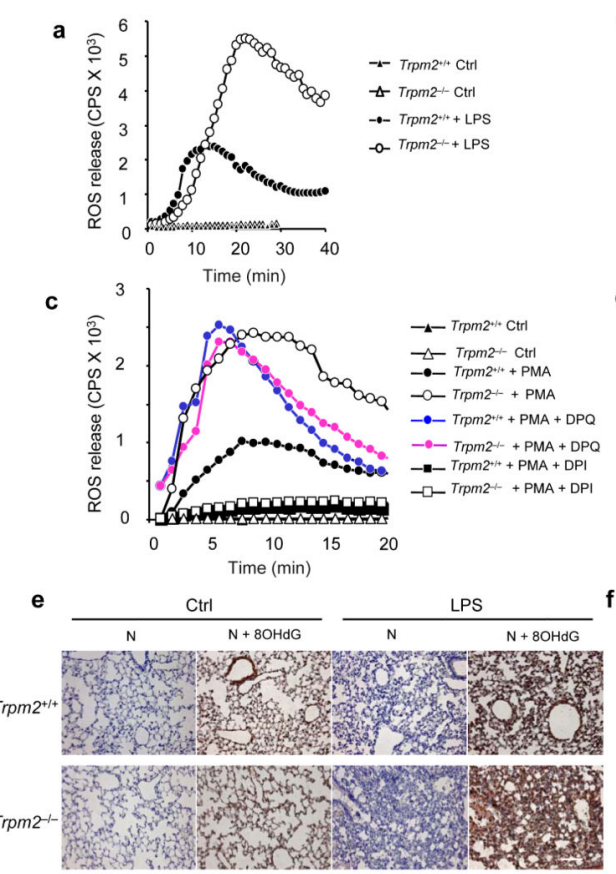
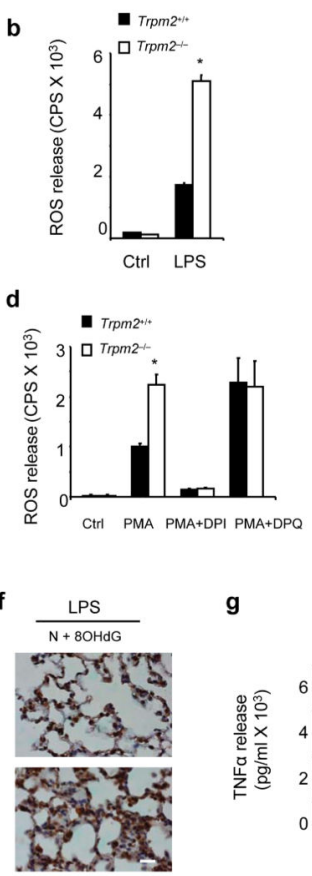

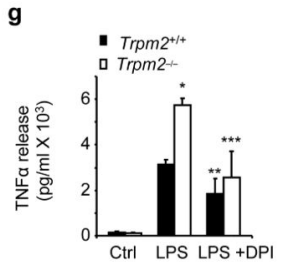

Figure 2. TRPM2 deletion enhanced ROS generation and oxidative lung inflammatory injury (a-d). TRPM2 ablation enhances ROS release from $\operatorname{Trpm}^{-/-}$PMN stimulated with LPS (1 $\mu \mathrm{g} / \mathrm{ml}, \mathbf{a}-\mathbf{b})$ and $\operatorname{Trpm} 2^{-/-}$BMDM stimulated with PMA ( $\left.1 \mu \mathrm{M}, \mathbf{c}-\mathbf{d}\right)$ compared with cells from $\operatorname{Trpm} 2^{+/+}$mice. $c p s=$ counts per second of light emitted. DPI prevented the increased ROS production in both $\operatorname{Trpm} 2^{+/+}$and Trpm $2^{-/-}$BMDM. Note that pretreatment with DPQ $\left(100 \mu \mathrm{M}, 30 \mathrm{~min}\right.$ at $\left.37^{\circ} \mathrm{C}\right)$ augmented ROS release in $\operatorname{Trpm} 2^{+/+}$cells but not in $\operatorname{Trpm} 2^{-/-}$ cells. ${ }^{*} p=0.00007(\mathrm{n}=3)$ in $\mathbf{b}$ and $* p=0.007(\mathrm{n}=6)$ in d. e-f. Immunohistochemical detection of 8-OHdG in lung sections from Trpm $2^{+/+}$and Trpm $2^{-/-}$mice challenged with LPS $(20 \mathrm{mg} / \mathrm{kg}$ ) for $20 \mathrm{hr}$ with lower magnification in e (scale bar, $100 \mu \mathrm{m})$ and higher magnification in $\mathbf{f}$ (scale bar, $20 \mu \mathrm{m}$ ). Nuclei were stained with hematoxylin (blue color, labeled as " $\mathrm{N}$ " in the figure). 8-OHdG (brown color) expression was weak in untreated mouse lung (control) and was increased after LPS stimulation in both $\operatorname{Trpm} 2^{-/-}$and Trpm $2^{+/+}$group. (g). Augmented LPS-induced production of TNFa from mouse BMDM was NADPH oxidase sensitive. ${ }^{*} p=0.00003(\mathrm{n}=7)$ compared to $\operatorname{Trpm} 2^{+/+}+$LPS group; $* * p=0.046(\mathrm{n}=3)$ compared to $\operatorname{Trpm} 2^{+/+}+$LPS group. ${ }^{* * *} p=0.013(\mathrm{n}=3)$ compared to $\operatorname{Trpm}^{-/-}+$LPS group. 

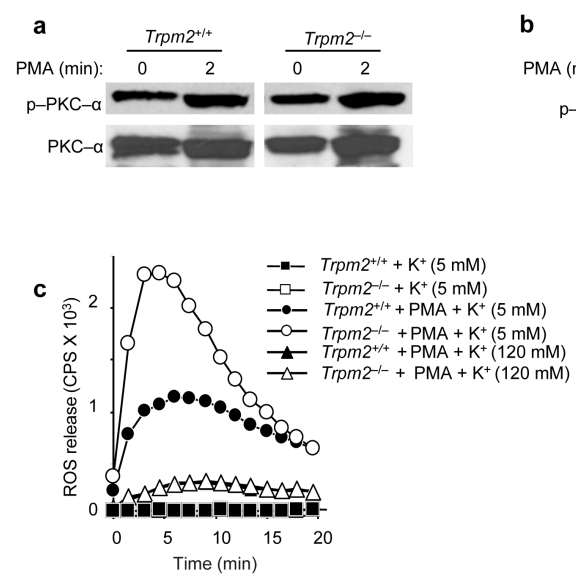
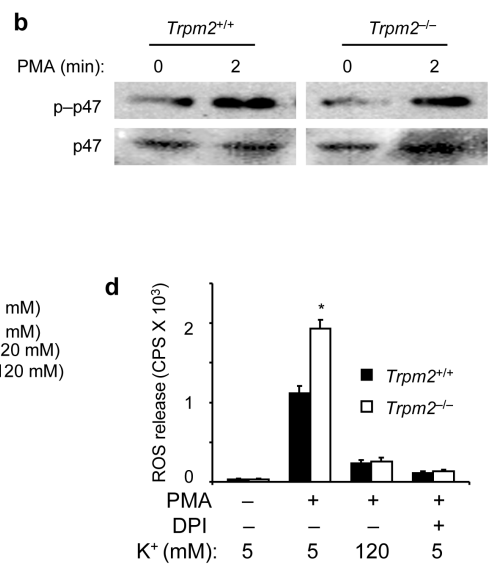

Figure 3. TRPM2 had no effect on phosphorylation of PKCa and p47 phox and high extracellular potassium inhibited ROS production in both $\operatorname{Trpm} 2^{-/-}$and $\operatorname{Trpm} 2^{+/+}$macrophages (a) Phosphorylation of PKCa of BMDM from Trpm $2^{+/+}$or Trpm $2^{-/-}$mice. BMDM were stimulated with PMA $(1 \mu \mathrm{M})$ for $2 \mathrm{~min}$. Equal protein loading was verified by membrane probing with anti-PKCa antibodies. TRPM2 expression did not affect phosphorylation of PKCa in BMDM stimulated with PMA. (b) Phosphorylation of p47phox of BMDM pretreated with PMA $(1 \mu \mathrm{M})$ for 2 min. Phosphorylation was evaluated by immunoprecipitation of $\mathrm{p} 47^{\text {phox }}$ and immunoblotting with antibodies against phosphoserine and $\mathrm{p} 47^{p h o x}$. Note that TRPM2 expression did not regulate the phosphorylation of $\mathrm{p} 47^{\text {phox }}$ in BMDM stimulated with PMA. (c) Representative curves of ROS release in BMDM from both $\operatorname{Trpm}^{+/+}$BMDM and Trpm2 $2^{-/-}$BMDM under different extracellular potassium concentration $\left(\left[\mathrm{K}^{+}\right]_{\text {out }}\right.$ ). These curves showed that pre-depolarization of BMDM by incubating cells with high $\mathrm{K}^{+}(120 \mathrm{mM})$ abrogated the differences in ROS production between $\operatorname{Trpm}^{+/}$and Trpm $2^{-/-}$BMDM stimulated with PMA $(1 \mu \mathrm{M})$. cps, counts per second of light emitted. (d) Summary of data obtained in (C). The figure shows ROS generation decreased with high extracellular concentration of $\mathrm{K}^{+}$which depolarized the cell plasma membrane. ${ }^{*} p=0.015(\mathrm{n}=5)$ compared with $\operatorname{Trpm} 2^{+/+}$group. 


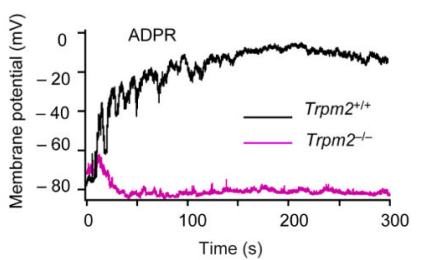

c

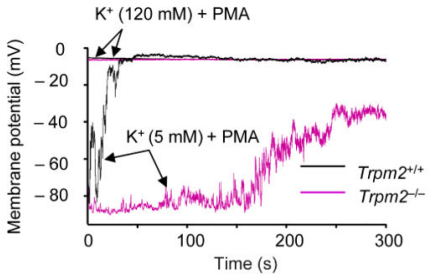

e

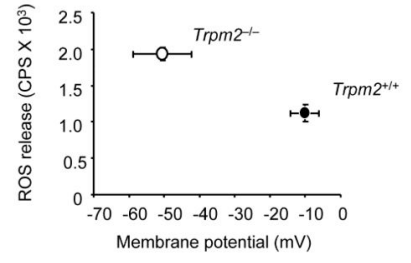

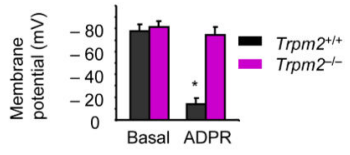

d

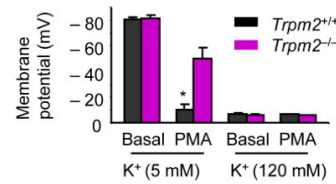

f
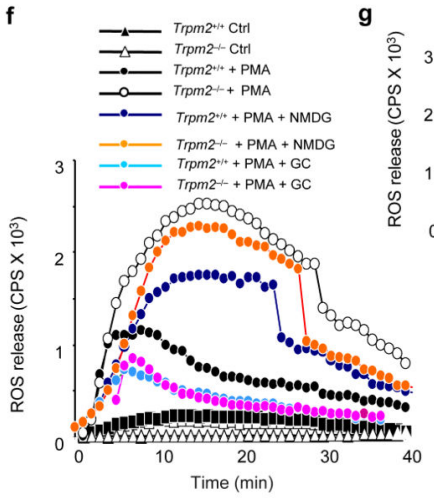

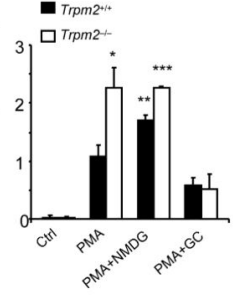

Figure 4. TRPM2 inhibited ROS production in macrophages through plasma membrane depolarization

(a-b) The TRPM2 activator ADPR failed to depolarize the plasma membrane in the absence of TRPM2 expression in BMDM. Representative curves showing plasma membrane potential changes are shown in (a) and the summary is shown in $(\mathbf{b}) . * p=0.0005(\mathrm{n}=6)$ compared with Trpm $^{-/-}+$ADPR group. (c-d) PMA $(1 \mu \mathrm{M})$ failed to fully depolarize the plasma membrane in the absence of TRPM2 expression in BMDM. Representative curves showing changes in plasma membrane potential are shown in (c) and summary is shown in (d). ${ }^{*} p=0.0005(\mathrm{n}=15)$ compared with $\operatorname{Trpm} 2^{+/+}$group. (e) Correlation of membrane potential with ROS production in BMDM. Figure is reconstituted partly from data shown in Figure 3d and Figure 4d. Cells were stimulated with PMA $(1 \mu \mathrm{M})$ in the presence of $5 \mathrm{mM}$ $\mathrm{K}^{+}$in the extracellular solution. (f-g) ROS release in both $\operatorname{Trpm} 2^{+/+}$and Trpm $2^{-/-}$BMDM stimulated with PMA $(1 \mu \mathrm{M})$ under physiological and controlled membrane potential. These curves show that pre-depolarization of BMDM by incubating cells with gramicidin (GC, $40 \mu \mathrm{g} / \mathrm{ml}$ ) not only inhibited ROS release from both $\operatorname{Trpm} 2^{+/+}$BMDM and Trpm $2^{-/-}$ BMDM, but also abrogated the differences in ROS production between $\operatorname{Trpm} 2^{+/+}$and Trpm2 $2^{-/}$BMDM. Note that replacement of $\mathrm{Na}^{+}$with NMDG augmented ROS release in Trpm $2^{+/+}$BMDM while it had little effect of ROS release from Trpm $2^{-/-}$BMDM. * $p=$ $0.0003(\mathrm{n}=6)$ and ${ }^{* *} p=0.0006(\mathrm{n}=4)$ compared to $\operatorname{Trpm} 2^{+/+}+$PMA group. 
a

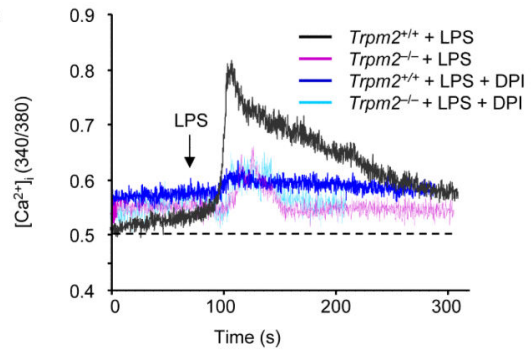

c
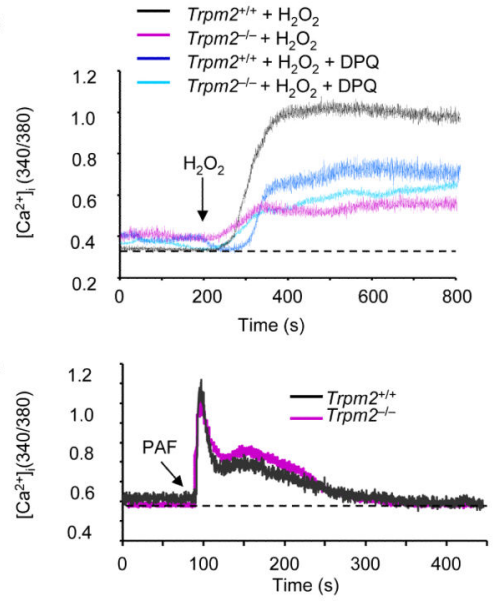

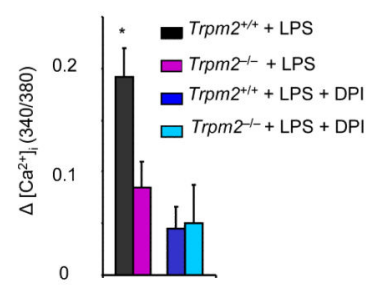

d
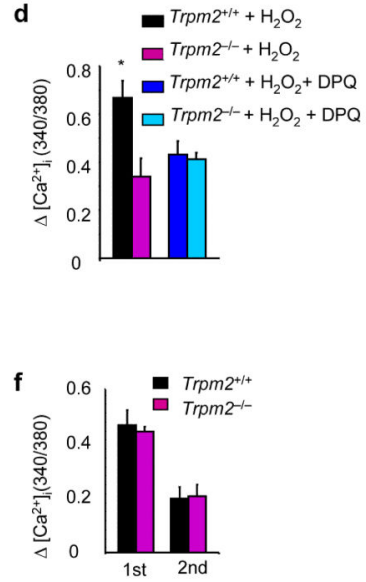

Figure 5. LPS -induced $\mathrm{Ca}^{2+}$ entry in macrophages was dependent on TRPM2 expression (a-b). TRPM2 ablation reduced LPS-induced ROS-dependent $\left[\mathrm{Ca}^{2+}\right]_{\mathrm{i}}$ increase in mouse macrophages. Typical recordings are displayed in $\mathbf{a}$ and the average results are shown in $\mathbf{b}$. LPS $(1 \mu \mathrm{g} / \mathrm{ml})$ induced a rapid $\left[\mathrm{Ca}^{2+}\right]_{\mathrm{i}}$ increase in $\operatorname{Trpm}^{+/+} \mathrm{BMDM}$ but $\left[\mathrm{Ca}^{2+}\right]_{\mathrm{i}}$ increase induced by LPS was significantly reduced in $\operatorname{Trpm} 2^{-/-}$BMDM. The $\left[\mathrm{Ca}^{2+}\right]_{\mathrm{i}}$ increase in Trpm $2^{+/+}$cells pretreated with DPI $(1 \mu \mathrm{M})$ was reduced to the same level as in $\operatorname{Trpm} 2^{-/-}$ cells treated with same amount of DPI. Data are mean of changes in ratiometric values from basal to steady-state $\left[\mathrm{Ca}^{2+}\right]_{\mathrm{i}} \cdot{ }^{*} \mathrm{p}=0.001(\mathrm{n}=5)$ compared with Trpm $2^{-/}$group. $(\mathbf{c}-\mathbf{d})$. DPQ-pretreatment reduced $\mathrm{H} 2 \mathrm{O} 2$-induced $\left[\mathrm{Ca}^{2+}\right]_{\mathrm{i}}$ increase in mouse macrophages. Typical recordings are displayed in $\mathbf{c}$ and the average results are shown in $\mathbf{d} .{ }^{*} \mathrm{p}=0.008(\mathrm{n}=7)$ compared with Trpm $2^{-/-}$group. (e-f). TRPM2-ablation did not altered PAF-induced $\left[\mathrm{Ca}^{2+}\right]_{\mathrm{i}}$ increase in mouse macrophages. Typical recordings are displayed in $\mathbf{c}$ and average results are shown in d. PAF $(0.1 \mu \mathrm{M})$ induced a rapid $\left[\mathrm{Ca}^{2+}\right]_{\mathrm{i}}$ increase followed by a slow $\left[\mathrm{Ca}^{2+}\right]_{\mathrm{i}}$ increase in both Trpm $2^{+/+}$BMDM and Trpm $2^{-/-}$BMDM. The amplitudes of the two peaks were calculated by measuring changes in ratiometric values from basal to steady-state $\left[\mathrm{Ca}^{2+}\right]_{\mathrm{i}}$ and summarized in $\mathbf{d}$. Data are mean of changes in ratiometric values from basal to steady-state $\left[\mathrm{Ca}^{2+}\right]_{\mathrm{i}}(\mathrm{n}=4-5)$. 